\title{
PReS-FINAL-2278: Description of a Colombian cohort of patients with childhood systemic lupus erytematosus
}

\author{
AS Diaz Maldonado*, A Monje Gaitan, F Gonzalez, N Gamba \\ From 20th Pediatric Rheumatology European Society (PReS) Congress \\ Ljubljana, Slovenia. 25-29 September 2013
}

\section{Introduction}

Systemic lupus erythematosus (SLE) is a multisystem disease of autoimmune etiology, which carries a high morbidity and mortality.

\section{Objectives}

To describe clinical and immunoserological features at the time of diagnosis within a cohort of pediatric patients attending the service of rheumatology of a Colombian pediatric hospital.

\section{Methods}

Cross-sectional study. 89 patients with diagnosis SLE (1986 ACR criteria) from a rheumatology center at a pediatric hospital were evaluated. Medical records were reviewed registering the following variables: sex, mean age, score SLEDAI, organ involvement, current pharmacological treatment and autoimmune profile. Descriptive analysis was done for qualitative and categorical variables (percentages and averages) using STATA11.

\section{Results}

76 patients $(85.4 \%)$ were female and $13(14.6 \%)$ were men. Mean age 11.3 y/o $(\min 2 \max 16)$. Median score SLEDAI at onset was $23(\min 4 \max 61)$. Organ involvement: Renal 75 patients $(84,3 \%)$, hematologic $75(84,3 \%)$, skin 60 $(67,4 \%)$, neurolupus $26(29,9 \%)$, serositis $17(19,1 \%)$, arthritis $50(56,18 \%)$, Raynaud $8(10,1 \%)$, photosensitivity 34 (52,3\%). Current pharmacological treatment: antimalarials 80 (93\%), Azathioprine 57 (64\%), Cyclophosphamide 33 $(38,8 \%)$, Mycophenolate Mofetil 8 (9,6\%), Rituximab 4 (4,5\%), Cyclosporine 1 (1,1\%). Autoimune profile: Antinuclear antibodies (ANAs) reactivity $74(88,1 \%)$,

Reumatologia Pediatrica, Hospital de La Misericordia, Bogota, Colombia
Anti-DNA antibodies 56 (66,7\%), Antiphospholipid antibodies (aPL) 25 (38,1\%).

\section{Conclusion}

The demographic characteristics and laboratory tests of this cohort are according to previously reported in worldwide and latin American literature. The score SLEDAI at the diagnosis was found in median activity. The most common medications prescribed were antimalarials followed by azathioprine and cyclophosphamide.

\section{Disclosure of interest}

None declared.

Published: 5 December 2013

doi:10.1186/1546-0096-11-S2-P268

Cite this article as: Diaz Maldonado et al:: PReS-FINAL-2278: Description of a Colombian cohort of patients with childhood systemic

lupus erytematosus. Pediatric Rheumatology 2013 11(Suppl 2):P268.

Submit your next manuscript to BioMed Central and take full advantage of:

- Convenient online submission

- Thorough peer review

- No space constraints or color figure charges

- Immediate publication on acceptance

- Inclusion in PubMed, CAS, Scopus and Google Scholar

- Research which is freely available for redistribution 